\title{
Identitas Politik dan Multikulturalisme: Penguatan Identitas Politik Etnis Tionghoa Pasca Orde Baru
}

\section{Political Identity and Multiculturalisme Strengthening Political Identity of Chinese in a Post New Order}

\author{
Suryani* \& Ana Sabhana Azmy** \\ Program Studi Ilmu Politik, Fakultas Ilmu Sosial dan Ilmu Politik \\ Universitas Islam Negeri Syarif Hidayatullah Jakarta, Indonesia \\ Program Doktoral Ilmu Politik, Fakultas Ilmu Sosial dan Ilmu Politik \\ Universitas Indonesia, Indonesia \\ Diterima: 13 Januari 2020; Disetujui: 25 Maret 2020; Diterbitkan: 01 Juli 2020.
}

\begin{abstract}
Abstrak
Gerakan reformasi 1998 menjadi titik awal dari banyak perubahan dinamika politik nasional di Indonesia. Etnis Tionghoa yang memiliki akar sejarah kultural yang cukup kuat di Indonesia menjadi salah satu bagian masyarakat yang memanfaatkan moment reformasi sebagai pintu masuk ke dalam peta politik praktis di Indonesia. Artikel ini menganalisis fenomena menguatnya identitas politik etnis Tionghoa di Indonesia pasca orde baru dan menelaah kaitan antara penguatan identitas politik etnis Tionghoa dan multikulturalisme di Indonesia. Dengan menggunakan metodologi kualitatif, data yang terkumpul dalam penelitian ini dianalisis dengan menggunakan teori identitas politik, konsep multikulturalisme, dan teori modal sosial. Setelah mengkaji dan menganalisis data, penulis menemukan beberapa hal yang berkaitan dengan penguatan politik identitas etnis Tionghoa di Indonesia pasca orde baru. Bahwa, terjadinya perubahan orientasi politik etnis Tionghoa dari yang pasif menjadi aktif yang disebabkan oleh beberapa faktor, diantaranya: adanya modal sosial yang kuat dan perubahan kebijakan pemerintah yang berkaitan dengan status kewarganegaraan. Dua hal tersebut ditunjang dengan multikulturalisme yang semakin dipahami dengan baik oleh masyarakat Indonesia.
\end{abstract}

Kata Kunci: Identitas Politik, Nasionalisme, dan Multikulturalisme.

\begin{abstract}
Reformation movement of 1998 being a starting point from so many dynamical changing of national politics in Indonesia. Chinese that has a strong historical root in Indonesia, being one of part of societies that used the reformation momentum as a way to involve into politics. This article analyzed the phenomena of strengthening Chines political identity post new order, and to analyzed the relation between strengthening Chinese political identity and multiculturalism in Indonesia.By using a qualitative methodolgy, those collected datas in this research, was analyzed by political identity theory, multiculturaism concept, and social capital theory. This research found that there are things that relate to the strengthening Chinese political identity post new order in Indonesia. The changing of political orientation of Chinese occured because the strong social capital and the changing of government policy that relate to the citizenship status. Those supported by a good understanding of multiculturalism by Indonesian society.

Keywords: Political Identity, Nationalism and Multiculturalism.
\end{abstract}

How to Cite: Suryani \& Azmy, A.S. (2020). Identitas Politik dan Multikulturalisme; Penguatan Identitas Politik Etnis Tionghoa Pasca Orde Baru. PERSPEKTIF , 9(2): 183-194.

${ }^{*}$ Corresponding author: ISSN 2549-1660 (Print)

${ }^{*}$ E-mail: survani@uinikt.ac.id ISSN 2550-1305 (Online)

**E-mail: anashabana.azmi@uinikt.ac.id 


\section{PENDAHULUAN}

Dalam penulisan sejarah Indonesia, peran aktif etnis Tionghoa hampir tidak pernah disebutkan secara proporsional, meskipun banyak bukti sejarah yang menunjukkan sumbangan mereka bagi perkembangan Indonesia, misalnya dalam bidang agama, kesusasteraan, bahasa, kesenian, olah raga, dan lain lain. Bahkan gambaran umum mengenai etnis Tionghoa di Indonesia yang ada selama ini adalah "stigma bahwa mereka merupakan kelompok penguasa ekonomi yang bersifat oportunis, tidak memiliki loyalitas politik, tidak nasionalis, dan hanya memikirkan kepentingan dan keuntungannya sendiri" (Kwartanada, 1996). Kalaupun masyarakat etnis Tionghoa disinggung dalam penulisan sejarah biasanya banyak berkaitan dengan peranannya di bidang ekonomi, baik sebagai pelaku utama atau sebagai penguasa jalur ekonomi yang banyak merugikan masyarakat pribumi.

Awal mula kedatangan orang-orang Tionghoa ke Indonesia dapat dilihat sejak masa dinasti Han (206 SM - 220 M). Pada saat itu, Tiongkok telah membuka hubungan perdagangan dengan negaranegara di sekitar kawasan Asia Tenggara. Saat itu pula telah ada orang Tionghoa yang datang ke Pulau Jawa (Djawa Dwipa). Pada masa Dinasti Tang (618 - 907 M) juga ada orang-orang Tionghoa di Kerajaan Sriwijaya. Pada masa kedua abad ke-9, saat tentara pemberontak pimpinan Huang Chao menduduki Guangzhou, muslim Tionghoa dan saudagar Arab serta Persia yang berjumlah besar dan bermukim di sekitar Guangzhou beramai-ramai mengungsi ke Sriwijaya. Selanjutnya, sebagaimana ditulis oleh Yuanzhi bahwa pada masa dinasti Ming, orang-orang Tionghoa datang bersamaan dengan ekspedisi Laksamana Cheng Ho sebanyak tujuh kali ke Nusantara (Yuanzhi, 2005). Pada saat kedatangan Cheng Ho yang pertama, telah banyak etnis Tionghoa di Pulau Jawa, Sumatera, dan Kalimantan.

Pada akhir masa dinasti Ming (13681644) dan awal Dinasti Ching (16441911), jumlah imigran etnis Tionghoa yang datang ke Nusantara semakin bertambah. Secara garis besar, orang Tionghoa di Indonesia sebagian berasal dari empat suku bangsa, yaitu Hokkien, Hakka atau Kheh, Tiu-Chiu, dan orang kota Kanton) (Purcell, 1987). Berdasarkan data sensus penduduk yang dilakukan oleh BPS pada tahun 2010, jumlah penduduk Indonesia berjumlah 237.641.326 jiwa dengan kurang lebih 1.300 suku. Etnis Tionghoa menempati urutan ke-18 dengan perolehan 1,22\% dan berjumlah sekitar 2.832.510 jiwa.

\section{Diagram I}

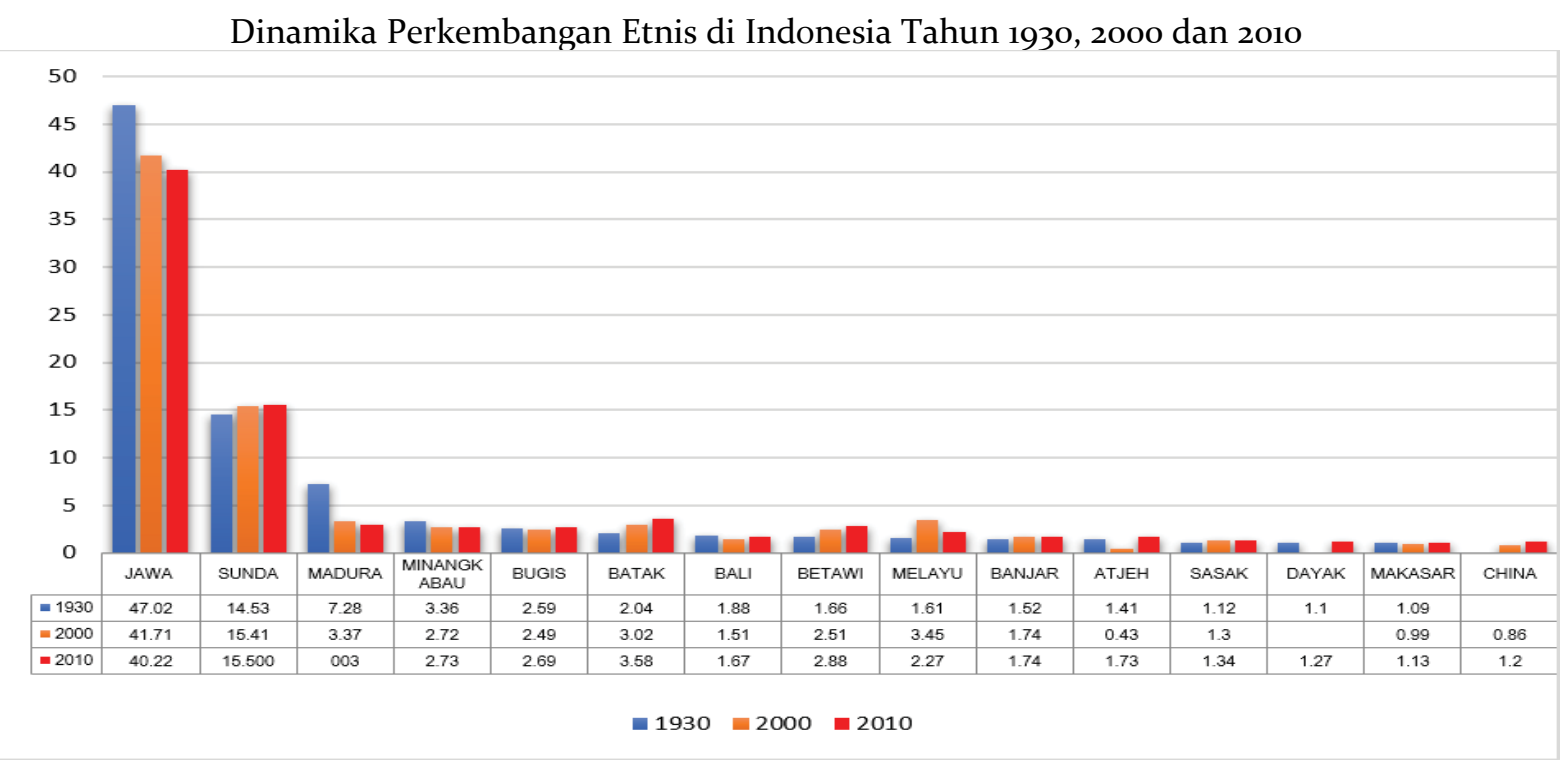

Sumber: Badan Pusat Statistik (BPS) 

Jumlah etnis Tionghoa menurut data BPS terus mengalami kenaikan sejak tahun 1930 an, yang masih berjumlah $0 \%$ lalu naik pada tahun 2000 menjadi 0,86\% (Pitoyo dan Triwahyudi, 2017)

Tabel 1.

Jumlah dan Persentase Penduduk Menurut Kelompok Suku Bangsa Berdasarkan Data Sensus Penduduk Tahun 2010

\begin{tabular}{cccc} 
No & Kelompok Suku & Jumlah & $\%$ \\
\hline 1 & Jawa & 95.217 .022 & 40.22 \\
2 & Sunda & 36.701 .670 & 15,5 \\
3 & Batak & 8.466 .969 & 3,58 \\
4 & Suku asal Sulawesi & 7.634 .262 & 3,22 \\
5 & Madura & 7.179 .356 & 3,03 \\
6 & Betawi & 6.807 .968 & 2,88 \\
7 & Minangkabau & 6.462 .713 & 2,73 \\
8 & Bugis & 6.359 .700 & 2,69 \\
9 & Melayu & 5.365 .399 & 2,27 \\
10 & Suku asal Sumatera Selatan & 5.119 .581 & 2,16 \\
11 & Suku asal Banten & 4.657 .784 & 1,97 \\
12 & Suku Asal NTT & 4.184 .923 & 1,77 \\
13 & Banjar & 4.127 .124 & 1,74 \\
14 & Suku Asal Aceh & 4.091 .451 & 1,73 \\
15 & Bali & 3.946 .416 & 1,67 \\
16 & Sasak & 3.173 .127 & 1,34 \\
17 & Dayak & 3.009 .494 & 1,27 \\
18 & Cina/Tionghoa & 2.832 .510 & 1,22 \\
19 & Suku asal Papua & 2.693 .630 & 1,14 \\
20 & Makassar & 2.672 .590 & 1,13 \\
& Sumber: Badan Pusat Statistik &
\end{tabular}

Berdasarkan data BPS tersebut, etnis Tionghoa menyebar hampir di seluruh wilayah Indonesia, namun kawasan utama penyebaran orang Tionghoa di Indonesia ada di wilayah Jabodetabek, Kalimantan Barat, dan Bangka Belitung (BPS) Di Indonesia, Istilah Tionghoa sendiri untuk pertama kalinya digunakan untuk menjadi nama perkumpulan Tiong Hoa Hwee Koan (THKK) yang didirikan tahun 1900, dalam dokumen organisasi tersebut istilah Tjina juga banyak digunakan untuk menyebutkan identitas mereka. Kebijakan Pemerintah Hindia Belanda saat masa penjajahan, mengharuskan orang Tionghoa untuk tinggal di satu daerah tertentu (wijkenstelsel) dan hanya boleh keluar dari area tersebut setelah mendapat kartu pass izin keluar.

Diskriminasi dalam bentuk politisasi identitas terhadap etnis Tionghoa tidak hanya terjadi pada masa pemerintahan Hindia Belanda, namun terus dilanjutkan pada masa setelah kemerdekaan, tepatnya pada era demokrasi liberal, diterapkan sebuah aturan yang disebut sistem benteng (Suryadinata, 1984) yang merupakan kebijakan yang dikeluarkan pemerintah untuk melindungi para importir nasional yang notabene nya adalah importir pribumi dari importir asing, dan para pengusaha Tionghoa tidak masuk dalam kategori importir nasional tersebut. Kebijakan lain yang makin meminggirkan kaum Tionghoa adalah saat Presiden Soekarno mengeluarkan PP No.10 tahun 1959 yang melarang orang Tionghoa melakukan perdagangan eceran di daerah pedesaan, peraturan ini membuat eksodus kaum Tionghoa dari daerah pedesaan ke pinggiran kota.

Politisasi identitas dilanjutkan oleh presiden Soekarno pada masa Orde Lama, yaitu saat muncul kampanye anti Guomindang (Kuomintang) di tahun 1958 karena campur tangan Taipei dalam 
pemberontakan di daerah. Sekolahsekolah China yang ada hubungannya dengan Kuomintang ditutup, dan pada tahun 1965 sebuah kudeta yang melibatkan kelompok komunis dapat digagalkan (Suryadinata, 1999). Saat itu Beijing dianggap terlibat dalam rencana kudeta tersebut sehingga pemerintah mengeluarkan beberapa aturan khusus bagi masyarakat etnis Tionghoa. Diantaranya, pelarangan terhadap penggunaan huruf Tionghoa, bahasa Tionghoa, pembatasan surat kabar Tionghoa, penutupan sekolah Tionghoa, pembatasan perayaan imlek dan cap go meh, pembatasan upacara di klenteng dan formalisasi penggunaan istilah Cina menggantikan Istilah Tionghoa yang sebelumnya di gunakan (homearticle.com, 2016). Pemerintah juga mengeluarkan TAP MPRS No. III/MPRS/1966 yang mengharuskan warga Tionghoa untuk mengindonesiakan nama mereka dan tidak menggunakan nama Cina sebagai identitas.

Proses demokratisasi dimulai setelah gerakan reformasi pada tahun 1998 yang dimulai dengan lengsernya Presiden Soeharto yang kemudian digantikan oleh Presiden BJ. Habibi memberikan energi dan semangat baru bagi bangsa Indonesia untuk berperan aktif mengambil bagian dalam mendukung ditegakkannya demokrasi. Hal ini ditandai dengan banyaknya partai politik baru yang didirikan dengan beragam ideologi dan basis massa, seperti partai-partai Islam dan yang berbasis massa Islam (PK, PKB, PAN, PNU, PBB, dan lain-lain), Partai berbasis Kristen (PDKB, PKNI, PKD), partai berorientasi sosialis (PRD, PSP, PBN, dan lain-lain), partai berideologi nasionalisme (PDIP, PNI Supeni, PKP, PIB, dan lain-lain). Makin meningkatnya semangat masyarakat untuk berperan dan berpartisipasi secara aktif dalam kegiatankegiatan politik, baik yang berskala lokal maupun yang nasional.

Pergeseran dari kebijakan asimilasi pada masa Orde Baru ke arah pembentukan masyarakat yang multikultural yang diusung oleh gerakan demokratisasi memunculkan permasalahan yang cukup penting untuk dikaji lebih dalam, yaitu; Bagaimana identitas politik etnis Tionghoa di Indonesia pasca Orde Baru? Dan bagaimana kaitan antara penguatan identitas politik etnis Tionghoa dan perkembangan multikulturalisme di Indonesia pasca orde baru?

Penulisan ini bertujuan untuk menjelaskan identitas politik masyarakat Tionghoa di Indonesia, dan menganalisis faktor-faktor yang melatarbelakangi menguatnya partisipasi politik etnis Tionghoa setelah orde baru. Selain itu, penelitian ini juga menganalisis hubungan antara menguatnya identitas politik etnis Tionghoa dan perkembangan multikulturalisme di Indonesia. Karena itu, beberapa teori digunakan sebagai alat analisis, seperti teori politik identitas yang dikemukakan oleh Castells (2003) dan dikembangkan oleh Heyes (2007), konsep multikulturalisme yang dikemukakan oleh Jarry (1999), Cashmore (1996), dan Kymlica (1995), serta teori modal sosial yang dikemukakan oleh Field (2014).

\section{METODE PENELITIAN}

Tulisan ini menggunakan metode kualitatif, yang dikatakan oleh Moleong bahwa penelitian kualitatif mempunyai makna sebagai penelitian yang dilakukan guna memahami fenomena dalam konteks sosial secara alami, dengan fokus pada kedalaman komunikasi antara peneliti dan orang yang diwawancara (Herdiansyah, 2010). Penulis mengumpulkan data dari berbagai buku, jurnal, artikel dan media massa serta website dan dokumen tertulis untuk mendukung penulisan penelitian. Setelah pengumpulan sejumlah referensi, penulis mulai untuk menganalisa topik pembahasan dengan menjawab pertanyaan yang ada dalam tulisan ini, menggunakan teori-teori yang telah disebutkan sebelumnya. 
Dalam membahas identitas politik dan multikulturalisme, penulis menggunakan pandangan Castells yang mengatakan bahwa identitas adalah sebagai atribut yang melekat pada seseorang secara kultural (Heyes, 2007). Masyarakat Tionghoa di Indonesia teridentifikasi sebagai kelompok masyarakat non pribumi yang terpisah dari masyarakat asli Indonesia, meski dalam diri mereka terdapat pula identitas kesukuan Indonesia seperti Batak (Cina Medan), Betawi (Cina Benteng), Bangka (Cina Bangka). Selain itu ada juga identifikasi Cina Peranakan sebagai etnis Tionghoa yang lahir dan besar di Indonesia dan berbahasa Indonesia (Suryadinata, 1986). Berbeda dengan Cina Totok yang asli keturunan Cina dari dua atau tiga generasi diatasnya dan hidup dengan budaya Cina serta menggunakan bahasa Cina sebagai bahasa utama dalam komunikasi (Tan, 2008).

Tidak hanya terjelaskan dengan identitas yang ditunjukkan oleh orang Tionghoa itu sendiri, identitas etnis ini juga menjadi klaim yang sudah dilekatkan oleh kelompok lain di luar etnis Tionghoa, seperti yang dikatakan oleh Castells bahwa: "Identities can also be originated from dominant institutions, they become identities only when and if social actors internalize them and construct their meaning around this internalization" (Castells,2003) Castells mengemukakan bahwa identitas tidak hanya tentang bagaimana individu mengidentifikasi dirinya sendiri, tetapi juga bagaimana kelompok dominan memberikan klaim dan menginternalisasi seseorang atau kelompok tertentu yang dilekatkan pada ciri-ciri dan stereotip yang dilekatkan pada mereka.

Menurut Castells, saat ingin menentukan konteks politik identitas, maka harus lebih dahulu dilakukan identifikasi. Identifikasi tersebut penting untuk melihat bagaimana konstruksi sebuah identitas muncul, yang menurut
Castells dapat dilihat melalui tiga model bentuk identitas, yaitu:

Legitimasi identitas; yang mempunyai makna identitas yang dibangun oleh institusi atau penguasa yang lebih mempunyai peran dalam kehidupan sosial. Institusi tersebut seringkali menunjukkan dominasinya dengan cara melekatkan identitas tertentu kepada seseorang atau kelompok.

Resistensi identitas; yang mempunyai makna identitas yang disematkan oleh aktor aktor sosial tertentu. Pemberian identitas ini dilakukan saat kondisi tertekan karena terdapat dominasi. Dominasi tersebut pada akhirnya menghadirkan penolakan dan membentuk identitas baru yang berbeda dari sebelumnya dan dari kebanyakan anggota komunitas sosial lainnya. Konstruksi identitas ini dimaknai sebagai politik identitas.

Proyek identitas; yang dimaknai sebagai konstruksi identitas yang dilakukan oleh aktor sosial dari kelompok tertentu. Hal tersebut bertujuan untuk membentuk identitas baru guna mencapai posisi posisi tertentu dalam masyarakat. Kondisi ini bisa terjadi sebagai implikasi dari gerakan sosial yang bisa mengubah struktur sosial secara keseluruhan.(Castells, 2003)

Masyarakat majemuk dapat diartikan sebagai masyarakat yang mempunyai dua elemen atau bahkan lebih, dimana elemen tersebut dapat dilihat dari tatanan hidup yang saling berdampingan tetapi tetap membaur dalam satu unit politik. (Furnivall, 1994) Hal ini dicontohkan dalam potret harmonis yang terjadi antara masyarakat Cina, India, dan Melayu yang dekat secara lokasi, tapi mempunyai budaya serta tradisi yang berbeda antara satu sama lain. Perbedaan tradisi tersebut faktanya mampu bekerjasama dalam bingkai kekuatan etnoreligius tanpa mengesampingkan identitas kultural masing-masing. 
Clifford Geertz berpandangan bahwa kemerdekaan nasional turut membuat sentimen-sentimen etno religius di negaranegara baru. Hal tersebut terjadi karena terpengaruhi oleh visi misi kemerdekaan yang ingin memiliki kontrol terhadap negara. (Geertz, 1993). Dalam pemahaman yang sederhana, multikulturalisme dapat dipahami sebagai pengakuan serta dorongan terhadap kemajemukan budaya; dimana budaya yang multi tentu berusaha untuk melindungi keanekaragaman budaya (sebagai contoh adalah bahasabahasa minoritas). Pada saat yang berbarengan, juga fokus pada hubungan budaya minoritas dengan budaya mayoritas yang kerapkali mempunyai ketidakseimbangan (Jarry, 1999). Menurut Kymlica, multikulturalisme merupakan upaya yang dilakukan oleh kelompok minoritas yang bergabung dalam satu etnis tertentu dan ingin berintegrasi ke dalam masyarakat yang lebih besar. Hal tersebut dilakukan sebagai upaya agar bisa diterima menjadi bagian dari masyarakat dominan dengan tujuan mencari pengakuan dan memberikan pengaruh agar undang-undang bisa mengakomodasi perbedaan yang dimiliki dan menerima mereka sebagai bagian integral dari masyarakat (Kymlica, 2002).

Cashmore menjelaskan bahwa dalam hubungannya dengan kebijakan negara, multikulturalisme mempunyai manfaat dan tujuan pada dua hal: (1). Dapat memelihara harmoni antara kelompokkelompok etnis yang beragam, (2) Dapat membentuk hubungan antara negara dan minoritas etnik yang ada (Cashmore, 1996).

Dalam teori modal sosial, konsep awal yang ada hanyalah digunakan pada bidang ilmu ekonomi yang memiliki makna "sejumlah uang yang diakumulasi yang dapat diinvestasikan dengan harapan akan memperoleh hasil yang menguntungkan dimasa yang akan datang"(Field, 2014). Selanjutnya, pada kisaran tahun 1960-an, dengan perspektif yang sama yaitu ekonomi, konsep tersebut mulai berkembang dengan memakai indikator manusia serta sejumlah hal seperti pendidikan, kesehatan, dan keterampilan sebagai alat pelengkap. Alat pelengkap tersebut digunakan karena bisa mengukur produktivitas dari investasi modal fisik, sebagai contoh adalah alat produksi. Fokus utama konsep modal sosial terletak pada jaringan sosial, dimana hal tersebut adalah aset berharga, serta sebagai dasar terjadinya kerekatan sosial. Kerekatan tersebut memberi ruang serta dorongan bagi orang untuk terikat satu sama lain dan saling memberikan manfaat.(Field, 2014)

Dengan mengutip Putnam (1993), Jhon field mendefinisikan modal sosial sebagai "bagian dari organisasi sosial, seperti kepercayaan, norma, dan jaringan, yang dapat memperbaiki efisiensi masyarakat dengan memfasilitasi tindakan terkoordinasi".(Field, 2014)

Dalam perspektif perilaku politik dan kaitannya dengan demokratisasi, modal sosial menitikberatkan pada fungsi-fungsi jaringan yang membentuk modal sosial yang oleh Putnam disebut sebagai civic community. Civic community adalah jaringan yang bekerja efektif baik secara vertikal maupun horizontal agar bisa membentuk civic engagement atau solidaritas sosial dan partisipasi massa yang berkorelasi tinggi dengan kinerja pembangunan ekonomi dan kualitas kehidupan demokrasi. Konsep modal sosial dinilai penting untuk menganalisa identitas politik etnis Tionghoa, karena melalui konsep ini kita dapat melihat pada modal atau bekal bagi etnis Tionghoa untuk masuk dalam politik aktif.

\section{HASIL DAN PEMBAHASAN \\ Patron-Klien dan Kekuatan Modal Sosial}


Dominasi ekonomi dan bisnis yang dibangun oleh etnis Tionghoa di Indonesia pada masa Orde Baru, memberikan banyak kontribusi bagi upaya mereka untuk bisa masuk dalam ranah politik praktis setelah gerakan reformasi digulirkan pada tahun 1998. Jika pada masa orde baru hubungan yang dibangun antara pemerintah dan kalangan pengusaha etnis Tionghoa bersifat kasat mata, maka pada masa reformasi dapat dilihat hubungan patron-klien tersebut dalam sejumlah hal, terutama dalam dunia politik. Modal sosial yang ditanam pada masa orde baru, semakin dikuatkan pada masa reformasi, kolaborasi hubungan patron - klien antara penguasa dengan pengusaha terus terjadi. Sebagai contoh adalah dukungan yang diberikan oleh pengusaha etnis Tionghoa dalam pencalonan Presiden dan Wakil Presiden. Dukungan ketika Pemilu Legislatif terjadi di Indonesia dan bahkan ketika etnis Tionghoa seperti Harry Tanoe S berpasangan dengan Wiranto dan menggunakan kendaraaan partai Hanura jelang pencalonan Pilpres 2014.

Hubungan pengusaha Tionghoa dan penguasa semakin terlihat ketika pengusaha etnis Tionghoa mempunyai bisnis media dan mendirikan partai politik, seperti Harry Tanoe yang pada akhirnya mendirikan Perindo. Hubungan tersebut menguatkan identitas yang dimiliki oleh etnis Tionghoa. Penguatan identitas tersebut bukan tanpa kekuatan modal sosial. Jaringan yang dimiliki oleh etnis Tionghoa, terutama kalangan pengusaha Tionghoa di banyak wilayah di Indonesia, adalah potret modal sosial yang sangat kuat. Sebagaimana pendapat Putnam (1993) yang dikutip oleh Jhon Field, bahwa yang dipahami sebagai modal sosial adalah "bagian dari organisasi sosial, seperti kepercayaan, norma, dan jaringan, yang dapat memperbaiki efisiensi masyarakat dengan memfasilitasi tindakan terkoordinasi" (Field, 2014).
Dalam buku Yoshihara Kunio, Kapitalisme Semu Asia Tenggara, dijelaskan bahwa di Indonesia, posisi para kapitalis pribumi lebih penting, tetapi mereka jauh kurang berarti dibandingkan dengan kapitalis Tionghoa. Sebagai contoh, dari kesepuluh bank swasta terbesar, hanya satu bank yang dikendalikan pribumi (Bank Niaga), dan diantara perusahaan-perusahaan manufaktur yang besar, Bakrie adalah satu-satunya kelompok utama, meskipun ada beberapa perusahaan manufaktur milik pribumi lainnya yang kurang dikenal. Akan tetapi, pribumi lebih penting dalam industri konstruksi dan jasa minyak-industriindustri yang dikaitkan dengan pemerintah (Kunio, 1990). Sesudah pemerintahan Soeharto, modal kalangan etnis Tionghoa menjadi bagian daripada modal dalam negeri, dan diskriminasi pun berakhir.

Koordinasi antar wilayah dengan wilayah lain, pusat dengan daerah menjadi mudah bagi kalangan pengusaha etnis Tionghoa karena mereka mempunyai jaringan dan kepercayaan yang dibangun antar mereka. Karena itulah pemerintah (sebagai patron) dan pengusaha Tionghoa (sebagai klien) ibarat dua sisi mata uang yang tidak bisa dipisahkan. Hal ini relevan dengan yang dinyatakan oleh Field bahwa yang menjadi fokus utama konsep modal sosial adalah pada bagaimana jaringan sosial dipandang sebagai aset yang sangat berharga. Tidak hanya itu, juga memberi titik dasar untuk terjadinya kerekatan sosial.

Hubungan patron-klien adalah hubungan yang bersifat tatap muka, artinya bahwa patron mengenal secara pribadi klien karena mereka bertemu tatap muka, saling mengenal pribadinya dan saling mempercayai. Lande ( dalam Scott 1972) menyebut hubungan patron-klien sebagai solidaritas vertikal. Ciri-ciri hubungan patron-klien menurut Scott (James, 1972) adalah; (1) terdapat suatu ketimpangan dalam pertukaran, 
bersifat tatap muka dan (3) bersifat luwes dan meluas. Hubungan patron-klien ini yang terjadi dalam dinamika terbentuknya partai politik yang dipimpin oleh pengusaha etnis Tionghoa, dan kemudian memiliki kedekatan dengan pemerintah.

Modal sosial yang dimiliki oleh etnis Tionghoa sulit untuk dibantah dan dibandingkan dengan modal sosial masyarakat Indonesia lainnya. Uphoff juga mengatakan bahwa modal sosial dapat dipahami secara mudah dengan mencirikan menjadi dua kategori; sktruktural dan kognitif. "Kategori struktural yaitu yang berkaitan dengan beragam bentuk organisasi sosial, khususnya peran-peran, aturan-aturan, preseden, dan prosedur-prosedur serta beragam jaringan-jaringan yang mendukung kerjasama yang memberikan manfaat bersama dari tindakan kolektif, dimana aliran manfaat tersebut merupakan hasil dari modal sosial. Sedangkan kategori kognitif datang dari proses mental yang menghasilkan gagasan/pemikiran yang diperkuat oleh budaya dan ideologi- norma-norma, nilainilai, sikap dan keyakinan yang berkontribusi pada terciptanya perilaku kerjasama "(Uphoff, 2000).

Pasca orde baru, kemandirian negara belum terbukti adanya, karena kekuatan modal sosial yang dimiliki oleh etnis Tionghoa tersebar dalam organisasiorganisasi dan berfungsi dengan tepat pasca orde baru/iklim reformasi. Suasana yang ada, tepat dengan penjelasan Fukuyama bahwa individu-individu yang bekerja dalam organisasi yang mempunyai berbagai fungsi kegunaan yang sangat kompleks yang mencakup kepentingankepentingan ekonomi individu, serta komitmen pada tujuan-tujuan dan nilainilai kelompok.

Kedekatan Soeharto dengan pengusaha etnis Tionghoa dimulai ketika dirinya masih aktif di militer. Pasca orde baru, purnawirawan yang aktif dalam dunia politik, masih menggunakan jaringan, modal sosial mereka untuk mendapat dukungan dari pengusaha etnis Tionghoa dalam politik. Pun sebaliknya, para pengusaha etnis Tionghoa juga membutuhkan kedekatan dengan pemerintah/penguasa untuk meneguhkan posisinya dalam bidang ekonomi dan bisnis.

\section{Pergeseran Orientasi Politik}

Menurut Leo Suryadinata, catatan sejarah mengenai orientasi politik etnis Tionghoa di Indonesia selalu mengalami perubahan sesuai dengan periodisasi kekuasaan politik di Indonesia (Suryadinata, 2010). Pembentukan orientasi politik baik yang bersifat sistemik maupun individual sangat bergantung pada budaya politik yang berkembang pada masyarakat setempat.

Dalam kehidupan politik, terdapat dua tingkat orientasi politik, yaitu tingkat individu dan tingkat masyarakat. Orientasi individu yang terdapat dalam sistem politik dapat dilihat dari tiga jenis orientasi, yaitu :

1. Orientasi Kognitif: Cara pandang yang meliputi berbagai pengetahuan dan keyakinan tentang sistem politik dan segala hal yang berhubungan dengan input dan outputnya. Hal ini berkaitan dengan aspek pengetahuan seseorang mengenai jalannya sistem politik.

2. Orientasi Afektif: Suatu orientasi yang menunjuk kepada aspek perasaan atau ikatan emosional seorang individu terhadap sistem politik yang meliputi peranannya, para aktor dan penampilannya

3. Orientasi Evaluatif: Suatu orientasi yang berkaitan dengan penilaian moral seseorang terhadap sistem politik dengan melibatkan kombinasi standar nilai dan kriteria dengan informasi dan perasaan, selain itu juga menunjukkan pada komitmen terhadap nilai-nilai dan pertimbangan-pertimbangan politik tentang kinerja sistem politik (Almond, 1984). 
Selanjutnya Almond dan Verba mengemukakan bahwa orientasi politik dapat dibuka secara sistematis jika memperhatikan beberapa hal pokok:

1. Adanya pengetahuan tentang negara dan sistem politiknya secara umum seperti sejarah, lokasi, ukuran, kekuasaan, sifat-sifat konstitusionalnya dan hal lainyang berkaitan dengan wawasan global sebuah kekuasaan politik.

2. Adanya pemahaman tentang struktur dan peranan kaum elit politik dan pengajuan pengajuan kebijaksanaan yang diperkenalkan ke dalam arus pembuatan kebijakan yang bersifat upward.

3. Pemahaman yang dimiliki yang berkaitan dengan implementasi kebijakan yang bersifat downward.

Bagaimana perasaan pribadi sebagai anggota dari sebuah sistem politik

Tabel 2.

Perubahan Orientasi Politik Etnis Tionghoa Setiap Periode Pemerintahan

\begin{tabular}{llll}
\hline No & Periode & & \\
\hline $\mathbf{1}$ & Masa & Kolonial \\
& Belanda & &
\end{tabular}

Tionghoa lokal adalah anggota bangsa Tiongkok, kelompok ini adalah

Tionghoa totok

Berorientasi ke Hindia Belanda (Chung Hua Hui) yang memahami posisi mereka sebagai kawula Belanda sambil melanjutkan kehidupan sebagai

Tionghoa peranakan.

Berorientasi sebagai bangsa Indonesia yang akan datang tergabung dalam Parta Tionghoa Indonesia dan merupakan Tionghoa peranakan.

2 Masa Kemerdekaan Pada masa ini etnis Tionghoa terbagi ke dalam 2 kelompok:

(Orde Lama) Berorientasi pada Tiongkok

Berorientasi ke Indonesia namun terbagi lagi menjadi dua kelompo, yaitu:

Kelompok integrasionis: yang tetap menginginkan identitasnya sebagai

Tionghoa peranakan

Kelompok Asimilasionis: yang menginginkan peleburan etnis Tionghoa ke dalam masyarakat pribumi Indonesia.

3 Masa Orde Baru Sebagian besar orang Tionghoa dikondisikan mengikuti kebijakan asimilasi yang diterapkan oleh penguasa dan membuat etnis Tionghoa menjadi terdiskriminasi dalam ruang politik

4 Masa Setelah Orde Semangat berpolitik etnis Tionghoa kembali muncul dan membentuk partai-partai politik Tionghoa, namun sebagian besar tokoh Tionghoa peranakan ingin mengambil jalan asimilasi dengan partai dan kelompok pribumi dengan tujuan agar identitas Tionghoa masih berakar kuat dikalangan golongan Tionghoa secara umum

Sumber: Leo Suryadinata (2010)

Arus reformasi yang dijadikan Tionghoa untuk menunjukkan sebagai pijakan dari komitmen etnis eksistensinya dalam dinamika politik di 
Indonesia ditunjukkan dengan beberapa cara, seperti pembentukkan partai politik, berasimilasi dengan partai nasionalis, masuk dalam struktur eksekutif sebagai pembuat kebijakan, terlibat secara langsung dan jelas dalam tender-tender pembangunan infra struktur, dan yang paling terlihat adalah dengan terlibat dalam kompetisi-kompetisi pada pemilihan pemilihan wakil rakyat baik pada Pemilu maupun dalam Pilkada di semua level dari yang tingkat kabupaten Kota sampai pada level nasional.

Hal tersebut dapat dilihat pada pemilu 1999, di mana terdapat sejumlah partai yang didirikan oleh etnis Tionghoa seperti Partai Reformasi Tionghoa Indonesia, Partai Pembauran Indonesia, dan Partai Bhineka Tunggal Ika yang menempatkan wakilnya di DPR, yaitu L Sutanto dari Kalimantan Barat. Terdapat etnis Tionghoa yang menjadi anggota DPR, seperti Rudianto Tjen yang datang dari fraksi PDIP. Tidak hanya di DPR, namun juga ada yang menjadi ketua DPRD kota Singkawang Kalimantan Barat, yaitu Tjhai Thui Mie. Berdasarkan data litbang kompas ada 15 orang dari 560 anggota DPR RI periode 2009-2014 yang merupakan keturunan Cina. Bahkan, sejumlah kepala daerah seperti wakil gubernur Kalbar, Christiandy Sanjaya dan walikota Singkawan Hasan Karman, juga merupakan keturunan Cina. Ada pula Basuki Thahaja Purnama yang merupakan wakil gubernur DKI Jakarta (nasional.kompas.com).

\section{Multikulturalisme dan Penguatan politik}

Nilai-nilai multikulturalisme yang ada dan menjadi dasar bagi demokratisasi di Indonesia, memberi ruang bagi seluruh masyarakat Indonesia untuk dapat berpartisipasi dalam pembangunan politik di Indonesia. Diskursus multikulturalisme kerapkali dihubungkan dengan konsep konsep kewarganegaran, sebagai contoh adalah konsep bangsa, etnis, suku dan penduduk.

Multikulturalisme sebagai nilai yang memiliki makna sebagai pengakuan juga dorongan terhadap pluralisme budaya; dan dalam waktu yang bersamaan juga berfokus pada hubungan budaya minoritas dengan mayoritas yang kerapkali memang tidak seimbang. (Jerry dan Jerry, 1999)

Negara sebagai institusi politik tertinggi mengakomodasi nilai nilai multikulturalisme yang berkaitan dengan status kewarganegaan etnis Tionghoa. Hal ini dapat dilihat dengan beberapa kebijakan yang dikeluarkan seperti:

1. Inpres No.26/1998 tentang Penghapusan Penggunaan Istilah Pri dan Non pri

2. Keppres No.6/2000 tentang Pencabutan Inpres No.14/1967

3. SE Mendagri No.471.2/1265/SJ tanggal 18 Juni 2002 tentang SKBRI

4. SE DIrjen Imigrasi Depkeh dan HAM No. P.U.M 01.100626 tanggal 14 April 2004 tentang SKBRI bagi Permohonan Paspor RI

5. SE Direktorat Penelitian dan Pengaturan Perbankan No.6 Tanggal 11 Juni 2004 tentang ditetapkannya Hari Tahun Baru Imlek sebagai Hari Nasional. (Mahfud, 2013)

6. Undang-Undang Republik Indonesia No. 12/2006 tentang Kewarganegaraan.

7. Undang-Undang No 23/ 2006 tentang Administrasi Kependudukan.

Undang-Undang Kewarganegaraan Republik Indonesia No. 12/2006 secara tegas menuliskan bahwa klasifikasi warga negara yang ada di Indonesia hanya WNI dan WNA, tidak ada istilah diskriminasi seperti "pribumi" dan "non pribumi". Undang-Undang tentang Administrasi Kependudukan No 23/ 2006 juga membatalkan semua UU diskriminatif peninggalan kolonial Belanda. Dikeluarkannya beberapa kebijakan tersebut memberikan ruang bagi 
masyarakat Tionghoa untuk demokratisasi di Indonesia. Sebagai berkedudukan sama di mata hukum.

Kebangkitan politik etnis Tionghoa ditandai dengan didirikannya beberapa organisasi masyarakat (ormas) yang berbasis etnis Tionghoa, seperti Perhimpunan INTI, SIMPATIK, ASPERTINA dan lainnya. Hal tersebut menjadi indikator menguatnya orientasi politik mereka setelah pada masa Orde Baru tidak satu pun ormas Tionghoa yang dibolehkan berdiri dan menjadi bagian dari kelompok kepentingan di Indonesia. Hal ini disebabkan Orde Baru memiliki kecurigaan yang besar bila ormas Tionghoa dibiarkan tumbuh dan berkembang maka akan dipengaruhi oleh kepentingan-kepentingan komunisme seperti yang disangkakan terjadi pada masa Orde Lama.

Ormas Tionghoa didirikan dengan beragam visi dan misi sebagai respon yang ditunjukkan oleh etnis Tionghoa atas dibukanya kran partisipasi politik pasca contoh, visi Perhimpunan INTI (Perhimpunan Indonesia Tionghoa) adalah; Menjadi organisasi yang maju, modern, bercitra internasional, berorientasi pada kebangsaan Indonesia, menghargai hak asasi manusia, egaliter, pluralis, inklusif, demokratis, dan transparan. Sedangkan misi yang mereka miliki adalah; Berperan aktif dalam dinamika proses pembangunan bangsa, antara lain penuntasan masalah Tionghoa di Indonesia, menuju terwujudnya bangsa Indonesia yang kokoh, rukun bersatu dalam keharmonisan, bhinneka, saling menghargai dan saling percaya (inti.or.id).

Berdasarkan visi misi Perhimpunan INTI, dapat dilihat bahwa etnis ini mempunyai misi untuk turut serta dalam membangun bangsa Indonesia yang kokoh dengan tidak memperdebatkan persoalan perbedaan etnisitas, di mana mereka mengalami hal tersebut di era orde baru. Berikut beberapa organisasi Tionghoa Orde Baru yang menandai proses yang didirikan setelah masa Orde Baru:

Tabel 3.

Organisasi Masyarakat Etnis Tionghoa Indonesia Yang Berdiri Setelah Masa Orde Baru

\begin{tabular}{|c|c|c|c|c|c|}
\hline No & Nama & Nama Lengkap & & Pendiri & $\begin{array}{l}\text { Tahun } \\
\text { Pendirian }\end{array}$ \\
\hline 1 & $\begin{array}{l}\text { Perhimpunan } \\
\text { INTI }\end{array}$ & $\begin{array}{l}\text { Perhimpunan } \\
\text { Tionghoa }\end{array}$ & Indonesia & $\begin{array}{l}\text { Drs. Edy Lembong alias Ong } \\
\text { Joe San (Wang Yousan) }\end{array}$ & 1999 \\
\hline 2 & PSMTI & $\begin{array}{l}\text { Paguyuban Sosial } \\
\text { Tionghoa Indonesia }\end{array}$ & Marga & $\begin{array}{l}\text { Brigjen TNI (Purn) Tedy Yusuf } \\
\text { alias Him Tek Ie, }\end{array}$ & 1998 \\
\hline 3 & SIMPATIK & $\begin{array}{l}\text { Solidaritas Pemuda } \\
\text { Untuk Keadilan }\end{array}$ & Tionghoa & & \\
\hline 4 & ASPERTINA & $\begin{array}{l}\text { Asosiasi Peranakan } \\
\text { Indonesia }\end{array}$ & Tionghoa & $\begin{array}{l}\text { Felix Ali Chendra, Tjandra } \\
\text { Ghozalli, Edison Jingga }\end{array}$ & 2011 \\
\hline
\end{tabular}

Sumber: data diolah dari berbagai sumber

Organisasi-organisasi civil society Tionghoa yang tumbuh subur juga dimanfaatkan sebagai sarana pendidikan politik bagi masyarakat etnis Tionghoa, secara berkala dilakukan pertemuanpertemuan seperti workshop, seminar, dan pelatihan bagi calon-calon legislatif yang berasal dari etnis Tionghoa.

Salah satu pertemuan yang dilakukan adalah silaturahmi caleg Tionghoa menjelang Pemilu 2014 di sebuah restoran di daerah Ancol yang diinisiasi oleh FORDEKA (Forum Demokrasi Kebangsaan) yang dihadiri oleh sekitar 20 orang calon legislatif dari etnis Tionghoa yang secara bergantian memaparkan visi misi serta program kerja bila terpilih sebagai anggota legislatif (Indonesia.media.com, 2016).

\section{SIMPULAN}

Dalam melihat bagaimana penguatan politik etnis Tionghoa di Indonesia pasca 
orde baru, ada dua hal penting yang dapat dianalisa. Pertama, orientasi politik dari etnis Tionghoa pasca orde baru dan kedua, penguatan identitas politik dengan keterlibatan etnis Tionghoa dalam politik praktis di Indonesia. Disahkannya UU Kewarganegaraan No.12/2006 yang menghapus istilah pribumi dan non pribumi dan menggantinya dengan istilah warga negara Indonesia dan non warga negara Indonesia, memberi gambaran mengenai upaya yang sudah dilakukan oleh pemerintah untuk mengakomodasi kepentingan legal identitas kewarganegaraan etnis Tionghoa.

Hal ini menjadi salah satu nilai dasar dari multikulturalisme dalam kehidupan demokrasi di Indonesia dengan memberikan keyakinan bahwa etnis Tionghoa mempunyai posisi yang sama dengan etnis-etnis lainnya yang ada di bumi Indonesia. Mereka memiliki kesamaan hak-hak sosial politik. Demokratisasi yang terjadi setelah adanya gerakan reformasi membuat masyarakat menjadi lebih terbuka pada eksistensi pluralitas.

Penelitian mengenai aktifitas politik etnis Tionghoa harus terus dikembangkan dengan menggali lebih dalam agendaagenda yang mereka miliki dalam konteks politik praktis. Salah satu hal yang penting untuk dikaji lebih dalam adalah apakah aktifitas politik praktis etnis Tionghoa di Indonesia dewasa ini hanya berkaitan dengan perjuangan mendapatkan hak-hak politik, atau ada kaitannya dengan upaya penguasaan sektor ekonomi yang lebih luas dalam hubungan antara patron-klien.

\section{DAFTAR PUSTAKA}

Buchari, S.A. (2014). Kebangkitan Etnis Menuju Politik Identitas. Jakarta: YOI.

Coppel, A,C. (1994). Tionghoa Indonesia Dalam Krisis. Jakarta: Pustaka Sinar Harapan.

Cashmore, E. (1996). Dictionary of Race and Ethnic Relations. London: Routledge.

Castells, M. (2003). The Power Of Identity: The Information Age, Economy, Society and Cultural. Australia: Blacwell Publishing Vol II.
Clifford, G. (1973). After the Revolution: The Fate of Nationalism in the New States. New York: Basic.

Dawis, A. (2010). Orang Indonesia Tionghoa Mencari Identitas. Jakarta: PT Gramedia Pustaka Utama.

Field, J. (2014). Modal Sosial. Bantul: Kreasi Wacana.

Furnivall, J.S. (1944). Netherlands India: A Study of Plural Economy. New York: Macmillan.

Gabriel, A. \& Verba, S. (1984). Budaya Politik : Tingkah Laku Politik dan Demokrasi di Lima Negara. Jakarta: Bina Aksara.

Hardiansyah, H. (2010). Metodologi Penelitian Kualitatif untuk Ilmu-Ilmu Sosial. Jakarta: Salemba Humanika.

James, S. (1972). Moral Ekonomi Petani. Jakarta: Yayasan Obor Indonesia.

Jarry D, J. Jary. (1999). Unwin Hyman Dictionary of Sociology, Second Edition. Leicester: Bookmart Ltd.

Kunio, Y. (1990). Kapitalisme Semu Asia Tenggara. Jakarta: LP3ES.

Kwartanada, D. (1996). "Minoritas Tionghoa dan Fasisme Jepang: Jawa, 1942-1945”, dalam Lembaga Studi Realino (ed.), Penguasa Ekonomi dan Siasat Pengusaha Tionghoa. Yogyakarta: Kanisius dan Lembaga Studi Realino.

Kymlica, W. (1995). Multicultural Citizenship. Cambridge: Cambridge University Press.

Mahfud, C. (2013) Manifesto Politik Tionghoa di Indonesia, Yogyakarta: PUSTAKA PELAJAR.

Ode M.D. La. (2012). Etnis Cina Indonesia Dalam Politik: Politik Etnis China Pontianak dan Singkawang di Era Reformasi 1998-2008. Jakarta: Yayasan Pustaka Obor Indonesia.

Ode M.D. La. (2013). Politik Tiga Wajah. Jakarta: Yayasan Pustaka Obor Indonesia.

Purcell, V. (1987). The Chinese in Southeast Asia. London: Oxford University.

Suryadinata, L. (1984). Dilema Minoritas Tionghoa. Jakarta: Grafiti Press.

Suryadinata, L. (2010). Etnis Tionghoa dan Nasionalisme Indonesia. Jakarta: Kompas.

Suryadinata, L. (1986). Politik Tionghoa Peranakan di Jawa. Jakarta: Pustaka Sinar Harapan.

Suryadinata, L. (1999). Etnis Tionghoa dan Pembangunan Bangsa. Jakarta: Pustaka LP3ES.

Tan, M.G. (2008). Etnis Tionghoa di Indonesia. Jakarta: Yayasan Obor Indonesia.

Uphoff, N. (2000). UnderstandingSocial Capital: Learning From The Analysis and Experience of participation dalam Dasgupta dan Serageldin. Social Capital A Multifaced Perspective, The World Bank. 
Suryani \& Ana Sabhana Azmy, Identitas Politik dan Multikulturalisme; Penguatan Identitas Politik Etnis

Wibowo, I. (2010). Negara Centeng; Negara dan Saudagar di Era Globalisasi, Yogyakarta: Penerbit Kanisius.

Pitoyo, A.J. \& Triwahyudi, H. (2017). Dinamika Perkembangan Etnis di Indonesia dalam Konteks Persatuan Negara. Yogyakarta: Jurnal Populasi UGM Yogyakarta, Volume 25 Nomor 1.

Heyes, C. (2007). Identity Politics, Stanford Encyclopedia of Philosophy. Diunduh pada September 2018 dari Plato.Stanford.edu/entries/identity politics. http://inti.or.id/about_us.html?id=106aaf2b-a4ca4cdb-b3d1-ee2e25848d9a, visi misi perhimpunan inti, diakses pada Mei 2019.

https://nasional.kompas.com/read/2011/01/31/0 2371831/twitter.com?page=all, Keturunan Cina mulai tampil, diakses pada Mei 2019. http://hukum.unsrat.ac.id/uu/uu_kewarganegaraa n_2006.htm, UU RI No.12 tahun 2006 tentang Kewarganegaraan Republik Indonesia, diakses pada September 2018 